IZA DP No. 5831

Bias in the Legal Profession: Self-Assessed versus Statistical Measures of Discrimination

Heather Antecol

Deborah A. Cobb-Clark

Eric Helland

July 2011 


\title{
Bias in the Legal Profession: Self-Assessed versus Statistical Measures of Discrimination
}

\author{
Heather Antecol \\ Claremont McKenna College \\ and IZA \\ Deborah A. Cobb-Clark \\ MIAESR, University of Melbourne \\ and IZA \\ Eric Helland \\ Claremont McKenna College
}

Discussion Paper No. 5831

July 2011

IZA

P.O. Box 7240

53072 Bonn

Germany

Phone: +49-228-3894-0

Fax: +49-228-3894-180

E-mail: iza@iza.org

Any opinions expressed here are those of the author(s) and not those of IZA. Research published in this series may include views on policy, but the institute itself takes no institutional policy positions.

The Institute for the Study of Labor (IZA) in Bonn is a local and virtual international research center and a place of communication between science, politics and business. IZA is an independent nonprofit organization supported by Deutsche Post Foundation. The center is associated with the University of Bonn and offers a stimulating research environment through its international network, workshops and conferences, data service, project support, research visits and doctoral program. IZA engages in (i) original and internationally competitive research in all fields of labor economics, (ii) development of policy concepts, and (iii) dissemination of research results and concepts to the interested public.

IZA Discussion Papers often represent preliminary work and are circulated to encourage discussion. Citation of such a paper should account for its provisional character. A revised version may be available directly from the author. 


\begin{abstract}

\section{Bias in the Legal Profession:} Self-Assessed versus Statistical Measures of Discrimination ${ }^{*}$

Legal cases are generally won or lost on the basis of statistical discrimination measures, but it is workers' perceptions of discriminatory behavior that are important for understanding many labor-supply decisions. Workers who believe that they have been discriminated against are more likely to subsequently leave their employers and it is almost certainly workers' perceptions of discrimination that drive formal complaints to the EEOC. Yet the relationship between statistical and self-assessed measures of discrimination is far from obvious. We expand on the previous literature by using data from the After the JD (AJD) study to compare standard Blinder-Oaxaca measures of earnings discrimination to self-reported measures of (i) client discrimination; (ii) other work-related discrimination; and (iii) harassment. Overall, our results indicate that conventional measures of earnings discrimination are not closely linked to the racial and gender bias that new lawyers believe they have experience on the job. Statistical earnings discrimination is only occasionally related to increases in self-assessed bias and when it is the effects are very small. Moreover, statistical earnings discrimination does not explain the disparity in self-assessed bias across gender and racial groups.
\end{abstract}

JEL Classification: J71, J15, J16, J44

Keywords: labor market discrimination, lawyers, gender and racial bias, wages

Corresponding author:

Heather Antecol

Robert Day School of Economics and Finance

Claremont McKenna College

500 E. 9th Street

Claremont, CA 91711

USA

E-mail: hantecol@cmc.edu

\footnotetext{
* We would like to thank participants at the Claremont McKenna College faculty workshop.
} 


\section{Introduction}

It is hard to deny that in the nearly fifty years since the adoption of the 1963 Equal Pay Act considerable progress has been made in achieving gender and racial equity in the U.S. labor market. Women, for example, now earn approximately 80 cents for every dollar that their male colleagues earn -- up from 60 cents on the dollar in the 1960s (see Blau et al. 2010). Much of the progress in closing the gender pay gap stems from the dramatic gains women have made in acquiring productive labor market skills. Young women today, for example, are more likely than young men to enroll in and complete postsecondary degrees leaving women the recipients of more than half of all bachelors and masters degrees (see Freeman 2004; Blau et al. 2010 for reviews), while women's growing labor market attachment has lead to a narrowing of the gender gap in occupational attainment and labor market experience. ${ }^{1}$ Progress in closing the gender pay gap has been particularly rapid among black workers for whom the female-to-male ratio of median earnings increased from 55 percent in 1955 to 86 percent in 2007 (Blau et al. 2010).

Despite these trends, there are many reasons to believe that many workers continue to confront discrimination in the labor market. First, closing the racial pay gap has proven to be much more challenging than closing the gender pay gap, particularly for men. The ratio of Hispanic-to-white median earnings among men has actually fallen from 72 percent (1975) to 60 percent (2007) (Blau et al. 2010), for example, and the progress that blacks have made in closing the racial earnings gap is overstated by the selectivity bias resulting from their high nonparticipation rates (see Brown 1984; Chandra 2000; Neal 2004). Second, labor market bias appears to be about much more than just race or gender. Homosexual men generally experience a wage penalty relative to their heterosexual counterparts, for example, though lesbians enjoy a

\footnotetext{
${ }^{1}$ For example, today the gap in men's and women's labor force participation rates stands at just 10 percentage points - a decline from 35 percentage points in 1972 (USDOL 2010a: Table 2).
} 
wage advantage relative to their heterosexual counterparts (e.g. Klawitter and Flatt 1998; Clain and Leppel 2001; Berg and Lien 2002; Black et al. 2003; Blandford 2003; Antecol et al. 2008). Third, statistical, residual-based decomposition approaches indicate that individuals' productive skills do not completely explain existing disparities in pay (see Blau and Kahn 2006; Neal and Johnson 1996). It is difficult to know how much of the "unexplained" portion of the pay gap is in fact the result of labor market discrimination, however audit studies, correspondence testing, and natural experiments have all been used to document that some employers do discriminate on the basis of race, sex, ethnicity, or sexual orientation (Kenney and Wissoker 1994; Riach and Rich 1991, 2002; Neumark et al. 1996; Goldin and Rouse 2000; Weichselbaumer 2001; Bertrand and Mullainathan 2003; Booth et al. 2009). Finally, and perhaps most importantly, many employees continue to believe that they are not being treated equitably by their employers. In 2009, for example, more than 61,000 new charges of employment discrimination on the basis of sex or race were filed with the U.S. Equal Employment Opportunity Commission (EEOC). This represents nearly a 17 percent increase over the number of cases filed a decade earlier. ${ }^{2}$

Given these trends, it is not surprising that there is intense interest in quantifying the extent of discrimination in the U.S. labor market. Economists have a long history of using statistical, regression-based methods to decompose the disparity in mean wages (Blinder 1973; Oxacca 1973) or in wage distributions (DiNardo et al. 1996; Machado and Mata 2005) to understand what can be attributed to differences in workers' productivity-related characteristics and what cannot. However, it is also recognized that labor market discrimination is "unlikely to be completely captured by so crude a measure as a log-earnings regression” (Kuhn 1990, pp. 297). Legal cases are generally won or lost on the basis of statistical discrimination measures,

\footnotetext{
${ }^{2}$ The EEOC is the federal agency responsible for enforcing federal laws that prohibit employment discrimination. See www.eeoc.gov for information on charge statistics.
} 
but it is workers' perceptions of discriminatory behavior that are important for understanding many labor-supply decisions. Workers who believe that they have been discriminated against are more likely to subsequently leave their employers, for example (Neumark and McLennan 1995; Johnson and Neumark 1997; Goldsmith et al. 2004), and it is almost certainly workers' perceptions of discrimination that drive formal complaints to the EEOC.

Interestingly, the relationship between statistical and self-assessed measures of discrimination is far from obvious. ${ }^{3}$ Employees do not have perfect information about the wage distribution they are facing and employers may exploit this information asymmetry by being more likely to discriminate when employees have less accurate information and the probability of reporting (and hence detection) is low (Barbezat and Hughes 1990). Empirically, some researchers have found that those women reporting the most sex discrimination, in fact, face the least statistical discrimination (Kuhn 1987, 1990; Barbezat and Hughes, 1990; Antecol and Kuhn, 2000), while others have found that that these measures are positively related (Hampton and Heywood 1993). The ambiguity of these results is not particularly surprising when one considers that many of those who perceive discrimination feel that it occurs along dimensions other than pay (Hallock et al. 1998) and that the phrasing of survey questions about discrimination is likely to matter (Hampton and Heywood, 1993). Finally, self-assessed discrimination measures allow broader concepts of gender and racial equity to be considered. In particular, self-assessed sex discrimination is only loosely related to other forms of gender bias that we might care about like sexual harassment (Antecol et al. 2009). ${ }^{4}$

\footnotetext{
${ }^{3}$ Statistical measures of labor market discrimination are generally derived as the residual difference in aggregate group outcomes which remain once observable productivity-related characteristics have been taken into account. It is well known, however, that omitted variables, unobserved heterogeneity, measurement error, feedback effects and pre-labor market discrimination can all confound residual-based estimates of labor market discrimination.

${ }^{4}$ It is important to note that while 28,028 sex discrimination charges were filed with the EEOC in 2009 only 942 cases were filed under the Equal Pay Act. This illustrates that the majority of sex discrimination are not simply based on pay but likely involve issues such as hiring decisions, promotion decisions, etc.
} 
This paper contributes to our understanding of discrimination by investigating the relationship between statistical measures and perceptions of discrimination within the legal profession. Lawyers provide a particularly interesting case for studying discrimination because courts routinely rely on circumstantial, statistical evidence in deciding whether an employment practice or process is discriminatory or not. $^{5}$ Consequently, lawyers have a detailed understanding of what constitutes employment discrimination for legal purposes and, presumably, how to avoid it - or at least avoid evidence of it. Laband and Lentz (1993) argue that this implies that any gender bias within the legal profession may disproportionately take more intangible forms making it important to investigate self-assessed discrimination measures. We expand on the previous literature by using information from the After the JD (AJD) study to compare standard Blinder-Oaxaca measures of earnings discrimination to self-reported measures of (i) client discrimination; (ii) other work-related discrimination; and (iii) harassment. The AJD data are unusually rich and contain several important indicators of ability including GPA, law-school rank, as well as indicators for clerkship experience, law review, and passing the bar on the first time. Moreover, while much of the previous literature is based on the experiences of graduates from elite law schools who may have particularly successful career trajectories, the AJD data allow us to analyze the employment experiences of a nationallyrepresentative sample of new lawyers for whom disparities may be more pronounced (Dinovitzer et al. 2009). Finally, unlike previous researchers, we adopt a broad perspective on discrimination within the legal profession by assessing the inequities associated with race and sexual orientation as well as gender.

\footnotetext{
${ }^{5}$ In particular, civil cases are decided using a "balance of probabilities" or "more likely than not" standard, rather than on the "beyond a reasonable doubt" standard used in criminal cases. Strong statistical associations which are suggestive of causality in the social sciences can be used in courts to force employers to prove that their employment practices are not discriminatory (see Gastwirth 1997).
} 
We find evidence of a statistically significant wage gap between women and white heterosexual men even when we include a rich set of controls. In our most comprehensive specification the annual income gap between white heterosexual women and white heterosexual men is over $\$ 4,900$ a year while for minority women (including lesbians) the gap is over $\$ 9000$. We also find systematic differences between groups in reported discrimination with white heterosexual men reporting less harassment or discrimination either by clients or otherwise. These differences are not, however, generally explained by the estimated wage gaps. Only white heterosexual male lawyers who earn less than their colleagues with the same observable characteristics are significantly more likely to report that they have experienced demeaning comments and/or harassment or that clients have requested someone else to handle a matter; although the magnitude of the effect is very small. White heterosexual women, minority women (including lesbians), and minority men (including gay men) who -- based on their observed, earnings-related characteristics -- face earnings disparities relative to their white heterosexual male colleagues, are generally no more likely to report bias on the basis of their race, religion, ethnicity, gender, disability, or sexual orientation.

This paper proceeds as follows. In Section 2, we briefly review the institutional features of the legal profession which are particularly relevant for understanding disparities in lawyers' earnings. Section 3 describes the After the JD data set, our estimation sample, and the main variables of interest. Our conceptual framework and estimation strategy are set out in Section 4, while our estimation results follow in Section 5. Section 6 presents our conclusions and suggestions for future research. 


\section{The Labor Market for Lawyers}

Historically in the United States, law firms are organized as partnerships. The structure was relatively simple. ${ }^{6}$ Partners were the lawyers with an equity stake in their firm and who were entitled to a share of the firm's profit and losses. The firm's junior lawyers were associates who achieved partnership through an "up-or-out" promotion tournament. Associates entered the firm with a cohort of other lawyers who graduated from law school during the same year. The whole cohort advanced at the same pace, were paid the same salary, and were put up for partner at the same time. Stopping the clock was rare and there were few if any ways to remain at a firm if a lawyer was not either a partner or on a partnership track. Given the "lock-step" nature of the partnership track much of the debate about discrimination focused on the pipeline of women who were rising through the ranks of law firms rather than on differences in compensation between male and female associates. Differences in salaries between male and female lawyers was largely driven by the type of law practiced, differences in the associates salaries at firms men and women worked at, and the paucity of female partners (Scharf and Flom 2010).

This structure has changed significantly in the last decade in ways that may systematically disadvantage women. Increasingly law firms have grafted alternative tracks onto the old associate partner model. These include contract attorneys, staff attorneys, and non-equity partners. Each of these positions has a slightly different structure. Contract attorneys, for example, are not employees of the firm and are hired on a short term basis for specific projects. ${ }^{7}$ Staff attorneys, by contrast, are employees of the firm but are not on tenure track and hence receive less compensation and do not enjoy the same salary increases as associates. Perhaps because these positions can be part-time, unlike associates positions, they are disproportionately

\footnotetext{
${ }^{6}$ For a more detailed discussion of the historic and current structure of law firms see Scharf and Flom (2010).

${ }^{7}$ Scharf and Flom (2010) refer to contract attorneys as law's version of outsourcing.
} 
filled by women (Scharf and Flom 2010). The National Association of Women Lawyers (NAWL) finds that in 2009 over 60 percent of staff attorneys were women while women occupied only 46 percent of the partner track associate positions.

Even at the higher levels of the law firm the new tracks have created the possibility of salary divergence. The emergence of very large firms and an emphasis on profitability has intensified the focus on "rainmaking", i.e., generating new clients for the firm, and high billable hours, making the road to partnership more difficult (Galanter and Palay 1991). In addition, many law firms are beginning to abandon compensation systems which reward all partners equally in favor of a points-based, "eat-what-you-kill", compensation systems in which partners are remunerated on the basis of fees billed and clients generated (see Epstein et al. 1999). The most obvious manifestation of these changes is the creation of the so called non-equity partners. Non-equity partners do not have to purchase shares in the firm but are paid only a fixed salary and perhaps a bonus based on performance. Because they are presented to clients as "partners" firms typically will not disclose who is an equity partner versus a non-equity partner. However the NAWL survey finds that 27 percent of the non-equity partners in their survey are women while only 16 percent of the equity partners are women. ${ }^{8}$ The divergence of pay between these tracks suggests that there are now greater opportunities for disparity in salary based on race and gender.

Not all lawyers choose to enter private law firms of course. Many pursue alternative career paths working in government agencies, in business firms, or in solo practices where employer expectations and compensation rules are fundamentally different. Discretionary forms of compensation, e.g., bonuses, which can be an important source of earnings disparity in large private firms (see Dinovitzer et al. 2009), may be irrelevant in other employment settings. It is

\footnotetext{
${ }^{8}$ We are unaware of a similar survey concerning minorities.
} 
not surprising then that lawyers' earnings are closely linked to the sector (i.e., public versus private), size of firm, practice area, and region in which they are employed. ${ }^{9}$ Earnings are higher in larger firms and in big cities, for example. Moreover, the career paths of young associates are heavily reliant on whether or not they have the opportunity to connect with more senior lawyers and their clients and to work in more lucrative practice areas (Dinovitzer et al. 2009). Finally, family leaves or working part-time can reduce women's earnings and partnership chances (Donovan 1990; Epstein et al. 1995).

The legal profession is less racially and ethnically diverse than most other professions. Currently, 89 percent of lawyers and 90 percent of judges in the United States are white -- in comparison to 70 percent of the working-age U.S. population as a whole -- and less than one percent of lawyers are openly homosexual (ABA 2010). The American Bar Association (2010) has raised concerns about this issue and is promoting a number of strategies designed to increase the racial diversity of the legal profession. In contrast, women have entered the legal profession in record numbers. In 1975, only seven percent of lawyers were women, while in 2009 that proportion had risen to 32 percent (USDOL 2010b: Table 11; Wootton 1997).

This surge of women entering the legal profession has led to a large literature examining gender differences in lawyers' earnings. Much of this literature is based on cross-sectional analyses and concludes that women earn approximately 40 to 50 percent less than their male colleagues. Accounting for a range of individual characteristics including law school quality, academic achievement, job history, hours of work, and firm characteristics reduces, but does not eliminate, these gender differences in earnings (see Noonan et al. 2005 for a review). Noonan et al. (2005) take advantage of longitudinal data for two cohorts of graduates from the University of Michigan Law School and find that although the gender gap in lawyers' earnings is small

\footnotetext{
${ }^{9}$ See Dinovitzer et al. (2009), Noonan et al. 2005, and Wood et al. (1993) for particularly helpful reviews.
} 
immediately after passing the bar, 15 years later the gap is almost identical to that among white, full-time, full-year workers more generally (see also Wood et al. 1993). These sex-based earnings disparities cannot be explained by individuals' law school performance, work history, child bearing, or job characteristics and have not narrowed across succeeding cohorts of graduates. These are remarkable results given the degree of homogeneity in the educational background and training of University of Michigan lawyers.

Much less is known about the link between lawyers' race or sexual orientation and their earnings or about the process generating the earnings of lawyers from non-elite schools. Moreover, previous researchers have generally focused exclusively on statistical, residual-based measures of earning discrimination without considering men's and women's perceptions of the treatment they experience and the outcomes they achieve. ${ }^{10}$ This is unfortunate given the complexities of legal firms' compensation systems which effectively tie lawyers' earnings to the hours they work, the mentoring they receive, the cases they are assigned, and the clients they have access to. This makes it critical to begin to assess the relationship between statistical measures of earnings differences and perceptions of discrimination within the legal profession.

\section{The Data: After the JD (AJD): A Longitudinal Study of Careers in Transition}

We use data from the first wave of the After the JD (AJD): A Longitudinal Study of Careers in Transition which follows 10 percent of the individuals who passed the bar for the first time in 2000. These data are ideal for our purposes as they contain detailed information on individuals' demographic characteristics, educational backgrounds, firm characteristics, work histories, and earnings as well as their self-assessed experiences of work-related discrimination, client

\footnotetext{
${ }^{10}$ The exception is Laband and Lentz (1998) who analyse the effect of self-reported sexual harassment on job satisfaction, earnings, and job turnover.
} 
discrimination, and harassment. Information about the quality (i.e. rank) of the law school individuals attended, their law school performance (law school review, participation in moot court, and pro bono work) and the number of job offers they received allow us to directly account for differences in individuals' ability. Finally, geographic location is an important determinant of lawyers' earnings (see Dinovitzer et al. 2009 for a review) and we use the geographic indicators in the AJD data to account for any regional wage differences in lawyers' earnings. These detailed controls are critical to constructing valid statistical measures of discrimination.

\subsection{The Estimation Sample}

We restrict the sample to eligible respondents who were employed full-time (i.e., those working more than 35 hours per week), were practicing law at the time of the survey and were less than 45 years of age. We further restrict the sample to individuals who passed the bar after the date of their law degree as well as to those who were not in their current job more than two years prior to graduating law school. Finally, we restrict the sample to respondents who have complete information on all of the key variables of interest for our analysis leaving a final sample size of 2,694 respondents.

We create indicator variables to categorize new lawyers into one of the four following groups: (i) minority men (including homosexual men); (ii) minority women (including homosexual women); (iii) white (heterosexual) women; and (iv) white (heterosexual) men. Henceforth we refer to these groups as minority men, minority women, white women, and white men, respectively. Our sample includes 412 minority men, 449 minority women, 760 white women, and 1073 white men. 


\subsection{Annual Salaries and Reported Discrimination}

Table 1 reports the annual mean salaries for our four groups of new lawyers. The white male lawyers in our sample earn $\$ 88,751$ on average each year, while male lawyers who are members of minority groups earn $\$ 94,653$-- 6.2 percent more. Despite the similarity in their educational backgrounds, female lawyers earn substantially less than their male counterparts. Specifically, white women earn $\$ 82,165$ which is 8.0 percent less than white men, while minority women earn on average $\$ 82,409$, i.e., 7.7 percent less. The magnitude of this gender earnings gap among white lawyers is consistent with the earnings gap often found for lawyers in their first year of employment (Wood et al. 1993; Biddle and Hamermesh 1998), while the gender earnings gap among lawyers in minority groups is somewhat larger.

\section{Table 1 Here}

The men and women in our sample were asked whether or not they have experienced any of the following in their place of work as a result of their race, religion, ethnicity, gender, disability, or sexual orientation: (i) demeaning comments/harassment; (ii) client requests for someone else to handle a matter; or (iii) other form of discrimination. ${ }^{11}$ Using this information, we created three indicator variables which equal one for those respondents who report experiencing these forms of discrimination or harassment and zero otherwise.

Our results indicate that men who are members of minority groups are nearly four times as likely as white men to report that they have experienced demeaning comments or harassment at work (see Table 1). In particular, 11.1 percent of minority men report having been the victim of harassment, while 12.7 percent report having experienced other forms of discrimination. The incidence of perceived harassment and discrimination is even higher among female lawyers.

\footnotetext{
${ }^{11}$ For simplicity we will refer to these outcomes as harassment, client discrimination, and other discrimination respectively. "Other Discrimination” includes both missed assignment and other forms of discrimination.
} 
More than one in five white women (21.9 percent) and one in four minority women (25.3 percent) report experiencing harassing behavior at work, while female lawyers also report significantly more client and other discrimination than do their male colleagues. Interestingly, the disparity between white and minority women's perceptions of discrimination and harassment are not statistically significant, suggesting that at least with respect to these behaviors the issue is one of gender not of minority status.

We investigate the relationship between our indicators of harassment and discrimination in more depth in Table 2 by testing for significant differences across a series of conditional means. For example, columns 1 and 2 report the incidence of client and other discrimination among those who do and do not experience harassment. If harassment and discrimination are independent events, we would expect these conditional means to be the same. We find, however, that with few exceptions the incidence of both client and other discrimination is significantly higher among those individuals who report experiencing harassment than among those who do not. For example, among those white female lawyers who do not experience harassment only one in ten report experiencing client or other discrimination. Among those who do report harassment, these rates soar to 24.9 (client discrimination) and 49.6 percent (other discrimination). Similarly, the incidence of client discrimination is significantly higher among those reporting other forms of discrimination than for those who do not, e.g., 30.0 versus 9.8 percent for white women (see columns 5 and 6). Thus, it appears that harassing and discriminatory behavior may be closely intertwined within the legal profession. Alternatively, it 
may be that our measures of harassment and discrimination are simply too blunt to completely capture the specific nuances of gender and racial bias. ${ }^{12}$

\section{Table 2 Here}

\subsection{Observable Characteristics}

We control for the following demographic characteristics in the model: age, marital status, and presence of children. ${ }^{13}$ New lawyers are roughly 31 years of age irrespective of their group (see Table 3). In addition, white men are more likely to be married than are individuals in all other groups (65 percent) followed by white women (54 percent), minority men (51 percent), and minority women (42 percent). Finally, white (minority) men are 1.9 (1.6) times more likely to have children present than are white (minority) women.

\section{Table 3 Here}

Our estimation model also includes a number of controls to account for respondents' educational backgrounds. Specifically, we include indicators for directly entering law school, passing the bar exam on the first attempt, law school rank, participating in law review, pro bono work, and moot court while in law school, and leadership activities while in law school, as well as the number of additional job offers received and tenure on the current job.

Table 3 reveals that irrespective of their minority status or gender, roughly 60 percent of new lawyers do not go to law school directly. Minority men and women are less likely to go to law school directly (38 and 39 percent, respectively) than are white men (41 percent) and women (44 percent). Table 3 also shows that white men (women) are 9 (7) percentage points more likely to pass the bar on the first try relative to their minority counterparts. Interestingly, we find

\footnotetext{
${ }^{12}$ Antecol et al. (2009) find that when asked directly, men and women do appear to discriminate between incidents of sex discrimination and incidents of sexual harassment making the wording of survey questions regarding discrimination and harassment very important

${ }^{13}$ See Appendix Table 1 for variable definitions.
} 
that minorities are more likely to go to higher ranked schools relative to their white counterparts. Furthermore, all groups had roughly 3 additional job offers and 1.3 years of tenure on their current job. Women were also found to be more likely to participate in law review (3 to 4 percentage points depending on minority status) and do pro bono work (roughly 7 percentage points irrespective of minority status) while their male counterparts were more likely to participate in moot court (2 to 4 percentage points depending on minority status). Participation in pro bono work was also substantially higher among minorities than their white counterparts (roughly 7 to 8 percentage points depending on gender). Finally, women (minorities) were more likely to report taking a leadership role than their male (white) counterparts; roughly 4 (10) to 10 (15) percentage points depending on minority status (gender).

We also account for firm characteristics (indicators for firm type and firm size) in our analysis. According to Table 3, white men are more likely to be in private practice (80 percent) relative to minority men (72 percent), white women (76 percent) and minority women (66 percent). Minority women are more likely to work in government (24.6 percent), followed by white women (19.4 percent), minority men (18.6 percent), and white men (12.6 percent). White women are the least likely to be in solo practice (1 percent) compared to the other three groups (roughly 5 percent). In addition, minority men (women) tend to work in firms with roughly 17 (7) more employees than their white counterparts.

Finally we include a measure of average earnings for lawyers in the region in our analysis. Interestingly, white men are more likely to be working in regions with lower average wages $(\$ 79,810)$ while minority women are more likely to be working in regions with the highest average wages $(\$ 89,586)$, with minority men $(\$ 86,793)$ and white women $(\$ 82,124)$ falling in the middle. 


\section{Conceptual Framework and Estimation Strategy}

Our goal is to understand the relationship between standard statistical measures of job-related discrimination within the legal profession and lawyers' own perceptions of discrimination. Specifically, do statistical measures of discrimination accurately predict whether or not lawyers believe that they themselves have experienced employer or client discrimination or have been the victim of sexual harassment?

\subsection{Statistical versus Perceived Discrimination}

As the first step toward answering this question, we specify a series of group-specific earnings models as follows:

$$
y_{i}^{g}=X_{i}^{g} \beta^{g}+\mu_{i}^{g}+\varepsilon_{i}^{g}
$$

where $i$ indexes individuals and $g$ indexes our four target groups: minority men, minority women, white women, and white men. Moreover, $X_{i}$ is a vector of productivity-related characteristics including demographic characteristics, educational background, firm characteristics, and a measure of average earnings for lawyers in the region. ${ }^{14}$ Finally, $\mu_{i}^{g}$ captures unobserved, individual-specific factors driving earnings, $\beta$ is a vector of coefficients to be estimated, and $\varepsilon$ is an error term with the usual properties.

We then define two alternative statistical measures of earnings disparity. The first measure, $D_{i}^{1}$, captures the deviation between what an individual would be expected to earn if he or she were paid on the same basis as white men and what he or she actually earns. The second

\footnotetext{
${ }^{14}$ Specifically, personal characteristics include age, marital status, and the presence of children; educational background includes indicators for directly entering law school, passing the bar exam on the first attempt, law school rank, participating in law review, pro bono work, and moot court while in law school, and leadership activities as well as the number of job offers received and tenure; and firm characteristics include indicators for firm type (private, solo practice, government, other) and firm size.
} 
measure, $D_{i}^{2}$, reflects the difference between what one would earn if compensated in the same way as white men rather than as other members of one's racial/gender group are compensated. Specifically,

$$
\begin{aligned}
& D_{i}^{1}=\left(X_{i}^{g} \hat{\beta}^{m}-y_{i}^{g}\right) \\
& D_{i}^{2}=\left(X_{i}^{g} \hat{\beta}^{m}-X_{i}^{g} \hat{\beta}^{g}\right)
\end{aligned}
$$

These two statistical discrimination measures are clearly related. However, $D_{i}^{1}$ includes any effect of unobserved, productivity-related individual effects (for example ability) in estimates of the extent of earnings disparity, while $D_{i}^{2}$ ignores the earnings effects of individuals' unobserved

characteristics (i.e., $\left.\mu_{i}^{g}\right)$, focusing only on the difference in the returns $\left(\hat{\beta}^{m}-\hat{\beta}^{g}\right)$ to individuals' observed characteristics $\left(X_{i}\right)$. By definition, for white men equation (3) equals 0 .

Following Kuhn (1987), we assume that women and minorities use the information embodied in these statistical measures of discrimination -- along with private information about their own specific employment conditions, the treatment they have received from their firms and clients, etc. -- to develop views about whether they themselves have been the victim of discrimination or sexual harassment. Specifically, let the extent to which individual $i$ believes that he or she has been discriminated against be given by:

$$
P D_{i}^{*}=\gamma D_{i}^{j}+\omega_{i}+\eta_{i}
$$

where $\mathrm{j}=1,2$ and $\omega_{i}$ is non-statistical (Kuhn 1987) or intangible discrimination (Laband and Lentz 1993) which is observed by the individual, but not the econometrician and $\eta_{i}$ is a random error term. 


\subsection{Estimation Equation: The Probability of Reporting Discrimination}

Individuals are assumed to report that they have experienced discrimination whenever their latent perceived level of discrimination exceeds some threshold value, $z\left(k_{i}\right)$. These thresholds can be thought of as reflecting individuals' sensitivity to (or willingness to report) behavior that is potentially racially or gender biased. ${ }^{15}$ Specifically, the probability that an individual reports discrimination is given by:

$$
\operatorname{Pr}\left(P D_{i}=1\right)=\operatorname{Pr}\left(\gamma D_{i}^{j}+\omega_{i}>z\left(k_{i}\right)\right)
$$

where $\omega_{i}=\omega\left(X_{i}\right), \quad z\left(k_{i}\right)=\left(z X_{i}+\varphi_{i}\right) \eta_{i}$, and $\varphi_{i} \sim N\left(0, \sigma_{\varphi}^{2}\right)$ and $\operatorname{COV}\left(X_{i}, \varphi_{i}\right)=0$. Thus, we allow for the possibility that individuals' observed characteristics affect both the extent of nonstatistical (intangible) discrimination they experience as well as their sensitivity to those experiences, i.e., the threshold they use when reporting that discrimination has occurred. Given the data available to us, it is not possible to separately identify these two effects. ${ }^{16}$

This framework results in the following reduced-form estimation equation for the probability that a lawyer reports being the victim of client discrimination, other work-related discrimination, or harassment:

\footnotetext{
${ }^{15}$ Kuhn (1987) conceptualizes $Z\left(k_{i}\right)$ as the degree of certainty a woman has that her experiences represent "true" discrimination. It may also capture variation in individuals' beliefs about the specific events or experiences that are in fact discriminatory. In particular, there is evidence that views about which behaviors constitute sexual harassment have changed over time (Antecol and Cobb-Clark 2004), while many workers who experience unwanted sexual behavior at work do not necessarily label it as sexual harassment per se (see Antecol and Cobb-Clark 2006; Marin and Guadagno 1999; Magley, et al. 1999).

${ }^{16}$ Antecol and Kuhn (2000) use additional information on the extent to which women feel they are advantaged by their gender to separately identify these two effects. They find that young female jobseekers are more likely to report that they have been discriminated against because they are more sensitive to behavior that is not genderneutral.
} 


$$
\operatorname{Pr}\left(P D_{i}=1\right)=\operatorname{Pr}\left(a D_{i}^{j}+b \omega_{i}+c X_{i}>e_{i}\right)=\Phi(Z \delta)
$$

where $Z=\left(D_{i}^{j}, \omega_{i}, X_{i}\right), \delta=(a, b, c)$, and $\Phi$ is the standard normal cumulative density function.

\section{Results}

\subsection{Earnings Disparity among Lawyers: Statistical Measures of Earnings Discrimination}

We begin by considering the magnitude of the earnings gap across groups in order to set the context for our statistical analysis of earnings disparity. Specifically, each column in Table 4 corresponds to an earnings regression -- increasing in controls -- estimated on the full sample of lawyers including group indicators (omitted category is white men). The results (OLS coefficients and standard errors) allow us to assess how the earnings gap between groups changes as we account for differences in individuals' productivity-related characteristics.

\section{Table 4 Here}

Not surprisingly, we find that the size of the estimated earnings gap depends heavily on whether or not we account for group differences in productivity-related characteristics. A comparison of the unconditional differences in group earnings (column 1) and earnings gaps conditional on annual hours (column 2), for example, reveals that much of women's earnings disadvantage can be attributed to the lower hours that they spend working. Specifically, the earnings gap between minority women and white men is cut by 40 percent (from $\$ 6343$ to \$3750) and the gap between white women and white men falls substantially (from \$6586 to \$4231) once we simply account for individuals' annual hours of work. Moreover, the substantial earnings advantage enjoyed by male lawyers from minority groups over their white male colleagues disappears and becomes an earnings disadvantage as we progressively control for 
individuals' annual hours, personal characteristics, educational background, firm characteristics, and regional wages. Similarly, the earnings penalty faced by white women and minority women gets even larger once we begin to account for the factors (other than annual hours) associated with their productivity. Finally, it is interesting to note the important influence of firm characteristics and regional wages on the disparity in earnings between groups. Minority men, for example, are estimated to have an earnings advantage of $\$ 3500$ when we do not account for either firm characteristics or regional wages, and an earnings disadvantage of \$178 when we do. This indicates that on balance male lawyers from minority groups are employed in those firms and in those regions of the country where annual earnings are typically higher. Similar results hold for white and minority women.

Against this backdrop, we estimate equation (1) separately for each group and use the results to calculate the two alternative statistical measures of earnings discrimination given in equations (2) and (3) for each individual. ${ }^{17}$ The first measure $\left(D_{i}^{1}\right)$ includes the effect of any unobserved individual effects related to earnings in the estimate of earnings disparity, while the second $\left(D_{i}^{2}\right)$ ignores unobserved individual heterogeneity and considers only group differences in the returns to individuals' observed characteristics. Table 5 presents the mean results as well as the results at the 25th, 50th, 75th, and 99th percentile of the distribution. ${ }^{18}$

\section{Table 5 Here}

The results indicate that the statistical earnings gap between minority men and their white male colleagues is very small and negative, averaging only $\$ 423$ per year. Thus, compensating

\footnotetext{
${ }^{17}$ Our statistical measures of earnings discrimination will also reflect any effect of unobserved heterogeneity which is not accounted for by our controls.

${ }^{18}$ In each case, white men are the reference group. Therefore, $D_{i}^{2}=0$ for all white men. Moreover, since it is the case that $E\left(y_{i}^{g}\right)=E\left(X_{i}^{g} \hat{\beta}^{g}\right)$ the means of the two measures are the same.
} 
minority men on the same basis as white men would have only a trivial effect on their average annual earnings. In contrast, statistical earnings discrimination is much more substantial among female lawyers amounting to approximately \$5067 on average for white women and \$9373 for minority women. It is also important to note that there is a great deal of individual-level variation in our statistical measures of earnings discrimination. Those individuals in the lowest quartile have negative values indicating that their earnings would fall if they were paid on the same basis as white men, however, statistical earnings discrimination becomes quite sizeable for those in the top quartile of the distribution. Not surprisingly, the distribution of individualspecific measures of earnings discrimination is more disperse when we account for unobserved heterogeneity than when we do not.

Taken together these results indicate that the magnitude of the earnings disparity among recent law school graduates depends heavily on the characteristics of the groups being compared. In particular, earnings gaps across groups tend to increase -- rather than decrease -- as we increasingly control for individuals' productivity-related characteristics. This results in a great deal of variation in the extent to which individuals' would be expected to benefit from being compensated on the same basis as white men. We turn now to consider whether these differences in statistical measures of discrimination can help us to understand lawyers' propensity to report being subjected to employer discrimination, client discrimination, and harassment.

\subsection{The Link Between Perceived Bias and Statistical Measures of Earnings Discrimination}

Are those lawyers facing larger wage disparities also more likely to report experiencing harassment and discrimination? We answer this question by using probit regression to estimate 
the determinants of reported harassment, client discrimination, and other discrimination (see equation 6). We estimate three specifications. Model 1 includes a measure of earnings disparity which accounts for unobserved individual-specific effects (i.e., $D_{i}^{1}$ ), while Model 2 includes a measure which focuses only difference in the returns to individuals' observed characteristics (i.e., $D_{i}^{2}$ ). Model 3 does not account for statistical earnings discrimination at all. Both Models 1 and 2 also include group indicators and interactions which allow the effect of statistical earnings disparities to differ across groups. All models include a rich set of other controls. The results (probit marginal effects and standard errors) are reported in Table 6.

\section{Table 6 Here}

White male lawyers who earn less than their colleagues with the same observable characteristics are significantly more likely to report that -- as a result of their race, religion, ethnicity, gender, disability, or sexual orientation -- they have experienced demeaning comments and/or harassment or that clients have requested someone else to handle a matter (see Model 1). ${ }^{19}$ Thus, for white men, statistical earnings discrimination is related to an increase in perceived bias at work. These effects are small, however, with each $\$ 10,000$ gap in earnings associated with an increase in reported harassment of 0.6 percentage points and an increase in reported client discrimination of 0.7 percentage points. There is no relationship between earnings disparities and reports of other job-related forms of discrimination.

In general, the relationship between perceived bias and statistical earnings discrimination (as measured by $D_{i}^{1}$ ) is much the same for white women, minority women, and minority men. Only two of the $D_{i}^{1}$ by group interactions are statistically significant. Specifically, the

\footnotetext{
${ }^{19}$ In Model 1, the marginal effect of statistical earnings discrimination reflects the difference in reported bias among white men (the omitted group) facing different degrees of statistical earnings discrimination. The earnings discrimination by group interactions capture the difference (relative to white men) in this relationship for other groups.
} 
association between statistical earnings discrimination and perceived harassment is statistically smaller (by 0.8 percentage points with each $\$ 10,000$ gap in earnings) for minority men and women than it is for white male lawyers. In other words, minority men and women are less sensitive to measured earnings gaps between themselves and their white male colleagues when reporting harassment. In fact, -- unlike white male lawyers -- minority lawyers facing earnings disparities are no more likely to report harassment than are other minority lawyers who do not.

These results are based on Model 1 which accounts for the effects of unobserved, individual-specific effects when calculating the extent of earnings disparity (i.e. $D_{i}^{1}$ ). At the same time, women and minorities may judge the extent of statistical earnings discrimination they face not based on their own personal circumstances, but rather on the basis of the average earnings of colleagues in their group (i.e. $D_{i}^{2}$ ). We find, however, that there is no association between statistical earnings discrimination measured in this way and reports of harassment, client discrimination, or other forms of discrimination (see Model 2). None of the marginal effects of earnings discrimination or the discrimination by group interactions are statistically significant. ${ }^{20}$ In short, white women and minorities who -- based on their observed, earningsrelated characteristics -- face earnings disparities relative to their white male colleagues are no more likely to report bias on the basis of their race, religion, ethnicity, gender, disability, or sexual orientation.

Finally, it is important to note that accounting for statistical earnings discrimination does little to explain the difference across groups in the propensity of reporting harassment or discrimination. Minority men, for example, are approximately 13 percentage points more likely

\footnotetext{
${ }^{20}$ Since $D_{i}^{2}$ is not defined for white men, in Model 2 the marginal effect of statistical earnings discrimination reflects the difference in reported bias among white women (the omitted group) facing different degrees of statistical earnings discrimination. The interaction terms capture the difference in this relationship for minority men and women respectively.
} 
than white men to report harassment whether or not we account for statistical earnings discrimination. Similarly, the propensity of white and minority women to report harassment, client discrimination, or other work-related discrimination is generally unaffected by the inclusion of statistical earnings discrimination measures in our model.

Overall, our results indicate that conventional measures of earnings discrimination are not closely linked to the racial and gender bias that new lawyers believe they have experienced on the job. Statistical earnings discrimination is only occasionally related increases in self-assessed bias and when it is the effects are very small. Moreover, statistical earnings discrimination does not explain the disparity in self-assessed bias across gender and racial groups. It is interesting to note that these results for individuals entering the U.S. legal profession in 2000 are broadly consistent with previous results for representative samples of U.S. and Canadian workers surveyed in the 1970s. In particular, Kuhn (1987) finds that the extent of statistical earnings discrimination a woman faces is negatively -- not positively -- related to the probability she will report discrimination when asked in a confidential survey. He estimates a structural wage model and concludes that this surprising result is due to the fact that women place much greater weight on non-statistical evidence when formulating views about whether they have experienced discrimination. Barbezat and Hughes (1990) argue that this result is also consistent with employers simply indulging in more discrimination when employees have less information about relative outcomes and the probability of being detected is lower. Similarly, despite facing less statistical earnings disparity, young women are much more likely than older women to report facing discrimination when applying for a job suggesting that they may be more sensitive to gender bias (Antecol and Kuhn 2000). 


\section{Conclusions and Suggestions for Future Research}

Perceptions matter for the legal system. Because clients must typically initiate legal action either by filing a grievance or contacting an enforcement agency or a private attorney, whether or not an individual believes that he or she has experienced discrimination matters a great deal. However it is still the case -- irrespective of how egregious workers perceive employers' behavior to be -- that damages must be alleged in order for the case to proceed. Given this, the legal system has typically turned to the standard, "objective" measures of discrimination typically computed by economists (such as, wage gaps or gaps in unemployment durations) to provide evidence of the extent of damage. Yet the relationship between self-assessed and statistical measures of discrimination is far from obvious.

In this paper we examine recent After the JD (AJD) data on the labor market experiences of lawyers which contains information both on perceived discrimination and earnings. Lawyers are particularly useful for examining the link between statistical and self-assessed measures of discrimination because they have a better sense than most employees of whether or not the discrimination they perceive meets the legal threshold for remedial action. Moreover the timing of the AJD survey corresponds to changes in the market for lawyers that opened up the possibility of greater variation in earnings among those practicing similar types of law. Consistent with this, we find evidence of a statistically significant earnings gap between women (irrespective of minority status) and white heterosexual men even when we include a rich set of controls. In contrast, the statistical earnings gap between minority men and their white male colleagues is very small.

At the same time, white heterosexual women, minority women (including lesbians), and minority men (including gay men) all report significantly more harassment and discrimination 
than do their white heterosexual male counterparts. This self-assessed discrimination, however, is not highly correlated with our estimated statistical earnings gaps. Only white heterosexual male lawyers who earn less than their colleagues with the same observable characteristics are significantly more likely to report that they have experienced demeaning comments and/or harassment or that clients have requested someone else to handle a matter; although the magnitude of the effect is very small. White heterosexual women and minorities (irrespective of gender) whose observed earnings are significantly lower than their otherwise similar white heterosexual male counterparts, are no more likely than those paid the same as white heterosexual men to report bias on the basis of their race, religion, ethnicity, gender, disability, or sexual orientation.

These results are important in advancing our understanding of bias within the legal profession. However, they also leave open a number of puzzles yet to be resolved. In particular, while individuals can be compensated in discrimination cases for damages that are not related to income, it is rare for discrimination cases to proceed without any evidence that individuals have also experienced a reduction in income (Laycock, 2006). Given the tendency for courts to use statistical discrimination measures to gauge the extent to which that income reduction results from discrimination, it is surprising that there is not more of a relationship between statistical and self-assessed measures of discrimination. Why is the link between these measures so weak?

In moving forward, we need to know more about the pervasiveness of intangible (i.e., unrelated to income) forms of bias and their consequences for individuals’ legal careers. If selfassessed bias is not the result of earnings disparity, then what drives it? In particular, do the new complex organizational structures and compensation schemes within law firms provide opportunities for more intangible bias to occur? Unlike the "lock-step" nature of the old style 
partnership track, these new arrangements foster earnings diversity among colleagues doing similar work. To the extent that the source of this diversity is not fully transparent, information asymmetries may provide law firms with additional opportunities to discriminate among their employees (see Barbezat and Hughes 1990).

We also need to understand the consequences of self-assessed bias for individuals' future legal careers. How does believing that one has been subject to discrimination or harassment from ones’ employers, colleagues or clients affect lawyers' satisfaction with their legal careers? Will those who believe they have experienced bias leave the legal profession to pursue opportunities elsewhere? ${ }^{21}$

Finally, despite the rapid movement of women into the legal profession, we are only now beginning to understand how the outcomes of female lawyers differ to those of their male colleagues. Much more work needs to be done to understand the factors underlying bias along racial or sexual orientation lines. How do law firms' complex organizational structures and compensation systems affect outcomes for racial minorities, gay men, and lesbians? Although standard statistical measures of discrimination suggest that little earnings discrimination is taking place - at least with respect to minority men - self-assessed measures of discrimination and harassment suggest that bias remains a large problem for these groups. This is likely to hinder future efforts to fully integrate the legal profession.

\footnotetext{
${ }^{21}$ Antecol, et al. (2011a and 2011b) are examining some of these issues in companion papers.
} 


\section{References}

American Bar Association (ABA) 2010. Diversity in the Legal Profession: The Next Steps, American Bar Association, available at: www.americanbar.org.

Antecol, H, Barcus, V, and Cobb-Clark, DA 2009. "Gender-Biased Behavior at Work: What Can Surveys Tell Us About the Link Between Sexual Harassment and Gender Discrimination?”, Journal of Economic Psychology, Vol. 30(5), October, pp. 782-792.

Antecol, H and Cobb-Clark, DA 2004. "The Changing Nature of Employment-Related Sexual Harassment: Evidence from the U.S. Federal Government (1978 - 1994), Industrial and Labor Relations Review, Vol. 57(3), April 2004, pp. 443-461.

Antecol, H and Cobb-Clark, DA 2006. "The Sexual Harassment of Female Active-Duty Personnel: Effects on Job Satisfaction and Intentions to Remain in the Military, Journal of Economic Behavior and Organization, Vol .61, Issue 1, 2006, pp.55-80.

Antecol, H, Cobb-Clark, DA, and Helland, E 2011a. "The Determinants of Job Satisfaction in the Law Profession: The Role of Perceived Discrimination”, mimeo Claremont McKenna College.

Antecol, H, Cobb-Clark, DA, and Helland, E 2011b. "The Effect of Perceived Discrimination on Quitting Behavior in the Law Profession”, mimeo Claremont McKenna College.

Antecol, H, Jong A, and Steinberger, MD 2008. "The Sexual Orientation Wage Gap: The Role of Occupational Sorting and Human Capital", Industrial and Labor Relations Review, Vol. 61(4), July, pp. 518-543.

Antecol, H and Kuhn, P 2000. "Gender as an Impediment to Labor Market Success: Why Do Young Women Report Greater Harm?" Journal of Labor Economics, Vol. 18 (4), pp. 702 728.

Barbezat, D and Hughes, JW 1990. "Sex Discrimination in Labor Markets: The Role of Statistical Evidence: Comment”, American Economic Review, Vol. 80(1), March, pp. 277-286.

Bertrand, M and Mullainathan, S 2003. “Are Emily and Greg More Employable than Lakisha and Jamal? A Field Experiment on Labor Market Discrimination”, NBER Working Paper 9873, July.

Blau, FD, Ferber, MA, and Winkler, AE 2010. The Economics of Women, Men, and Work $6^{\text {th }}$ Edition, Upper Saddle River, NJ: Prentice Hall.

Blau, FD and Kahn, LM 2006. "The U.S. Gender Pay Gap in the 1990s: Slowing Convergence” Industrial and Labor Relations Review, Vol. 60(1), October, pp. 45 - 66. 
Blinder, AS 1973. Wage Discrimination: Reduced Form and Structural Estimates. Journal of Human Resources, Vol. 8, 436-455.

Booth, A, Leigh, A, and Varganova, E 2009. "Does Racial and Ethnic Discrimination Vary Across Minority Groups? Evidence from a Field Experiment”, unpublished working paper.

Brown, C 1984. "Black-White Earnings Ratios Since the Civil Rights Act of 1964: The Importance of Labor market Dropouts” Quarterly Journal of Economics, February 1984, 95(1), pp. $31-44$.

Chandra, A 2000. "Labor-Market Dropouts and the Racial Wage Gap: 1940-1990" American Economic Review, Vol. 90(2), May, pp. 333-338.

DiNardo, J, Fortin, NM, Lemieux, T 1996. "Labor Market Institutions and the Distribution of Wages, 1973-1992: A Semiparametric Approach” Econometrica 64, 1001-1044.

Dinovitzer, R, Reichman, N, and Sterling, J 2009. "The Differential Valuation of Women's Work: A New Look at the Gender Gap in Lawyers' Incomes" Social Forces, Vol. 88(2), December, pp. 819-864.

Donovan, K. 1990. "Women Associates’ Advancement to Partner Status in Private Firms." Georgetown Journal of Legal Ethics 4: pp. 135-152.

Epstein, CF, Sauté, R, Oglensky, B and Gever, M 1995. "Glass Ceilings and Open Doors: Women's Advancement in the Legal Profession.” Fordham Law Review 64(2): pp. 291449

Epstein, CF, Seron, C, Oglensky, B and Sauté, R 1999. The Part-Time Paradox: Time Norms, Professional Lives, Family and Gender. New York and London: Routledge.

Freeman, CE 2004. Trends in Educational Equity of Girls \& Women: 2004 (NCES 2005-016). U.S. Department of Education, National Center for Education Statistics. Washington, DC: U.S. Government Printing Office.

Galanter, M and Palay, T 1991. The Tournament of Lawyers: The Transformation of the Big Law Firm. Chicago: University of Chicago Press.

Gastwirth, JL 1997. "Statistical Evidence in Discrimination Cases", Journal of the Royal Statistical Society, 160, part 2, pp. 289-303.

Goldin, C and Rouse, C 2000. "Orchestrating Impartiality: The Impact of "Blind" Auditions on Female Musicians”, American Economic Review, 90(4), September, pp. 715-741. 
Goldsmith, AH, Sedo, S, Darity Jr., W, and Hamilton, D 2004. “The Labor Supply Consequences of Perceptions of Employer Discrimination During Search and On-the-job: Integrating Neoclassical Theory and Cognitive Dissonance”, Journal of Economic Psychology, 25, pp. 15-39.

Hampton, MB and Heywood, JS 1993. "Do Workers Accurately Perceive Gender Wage Discrimination?”, Industrial and Labor Relations Review, Vol. 47(1), October, pp. 36 49.

Hersch, J 2003. “The New Labor Market for Lawyers: Will Female Lawyers Still Earn Less?” Cardozo Women’s Law Journal. 10(1).

Johnson, RW and Neumark D 1997. “Age Discrimination, Job Separations, and Employment Status of Older Workers: Evidence from Self-Reports”, Journal of Human Resources, 32(4), pp. 770-811.

Kenney, GM. and Wissoker, DA 1994. “An Analysis of the Correlates of Discrimination Facing Young Hispanic Job-Seekers” American Economic Review, 84(3), June, pp. 674-683.

Kuhn, P 1987. "Sex Discrimination in Labor Markets: The Role of Statistical Evidence" American Economic Review, 77(4), (September), pp. 567-583.

Kuhn, P 1990. "Sex Discrimination in Labor Markets: The Role of Statistical Evidence: Reply" American Economic Review, 80(1), (March), pp. 290-297.

Laband, DN and Lentz BF 1998. "The Effects of Sexual Harassment on Job Satisfaction, Earnings, and Turnover among Female Lawyers" Industrial and Labor Relations Review 51, 594-607.

Laycock, D 2006. Modern American Remedies: Cases and Materials Aspen Law \& Business.

Machado, JAF and Mata, J 2005. "Counterfactual Decomposition of Changes in Wage Distributions using Quantile Regression”, Journal of Applied Econometrics, Vol. 20., pp. $445-465$.

Magley, VJ, Hulin, CL, Fitzgerald, LF, and DeNardo M 1999. "Outcomes of Self-Labeling Sexual Harassment.” Journal of Applied Psychology, Vol. 84, No. 3 (June), pp. 390-402.

Marin, AJ and Guadagno RE 1999. "Perceptions of Sexual Harassment Victims as a Function of Labeling and Reporting.” Sex Roles, Vol. 41, No. 11/12 (December), pp. 921-940.

Neal, D 2004. “The Measured Black-White Wage Gap Among Women is Too Small” Journal of Political Economy, Vol. 112 (1 pt. 2), S1 - S28.

Neal, D and Johnson, W 1996. "The Role of Premarket Factors in Black-White Wage Differences” Journal of Political Economy, Vol. 104(5), October, pp. 869-895. 
Neumark, D, Bank, RJ, Van Nort, KD 1996. "Sex Discrimination in Restaurant Hiring: An Audit Study”, The Quarterly Journal of Economics, 111(3), August, pp. 915-941.

Neumark, D and McLennan, M 1995. "Sex Discrimination and Women's Labor Market Outcomes”, Journal of Human Resources, 30(4), pp. 713-740.

Noonan, MC, Corcoran, ME and Courant, PN 2005. "Pay Differences Among the Highly Trained: Cohort Differences in the Sex Gap in Lawyers' Earnings" Social Forces, Vol. 84(2), December, pp. 853-872.

Oaxaca, RL 1973. “Male-female Wage Differentials in Urban Labor Markets”, International Economic Review 14, 693-709.

Riach, PA and Rich J 1991. "Testing of Racial Discrimination in the Labor Market”, Cambridge Journal of Economics, 15(3), pp. 239-259.

Riach, PA and Rich, J 2002. "Field Experiments of Discrimination in the Market Place”, The Economic Journal, 112(483), November, pp. F480-F518.

Rosen, S 1992. "The Market for Lawyers" Journal of Law and Economics, Vol. 35 (2), October, pp. 215 - 246.

Scharf, S and Flom BM (2010) "Report of the 2010 NAWL Survey on the Retention and Promotion of Women in Law Firms.” NAWL Foundation

USDOL (2010a), Labor Force Characteristics by Race and Ethnicity 2009 U.S. Department of Labor, Bureau of Labor Statistics, Report 1026, August 2010 available www.bls.gov.

USDOL (2010b), Women in the Labor Force: A Databook U.S. Department of Labor, Bureau of Labor Statistics, Report 1026, December 2010 available www.bls.gov.

Weichselbaumer, D 2001. "Sexual Orientation Discrimination in Hiring”, Linz Working paper No. 00-21.

Wood, RG, Corcoran, ME, and Courant PN 1993. "Pay Differences among the Highly Paid: The Male-Female Earnings Gap in Lawyers’ Salaries” Journal of Labor Economics, Vol. 11 (3), pp. 417 - 441.

Wootton, BH 1997. "Gender Differences in Occupational Employment" Monthly Labor Review, April, pp. 15 - 24. 
Table 1. Annual Salary, Raw Wage Gap, and Reported Harassment/Discrimination by Group

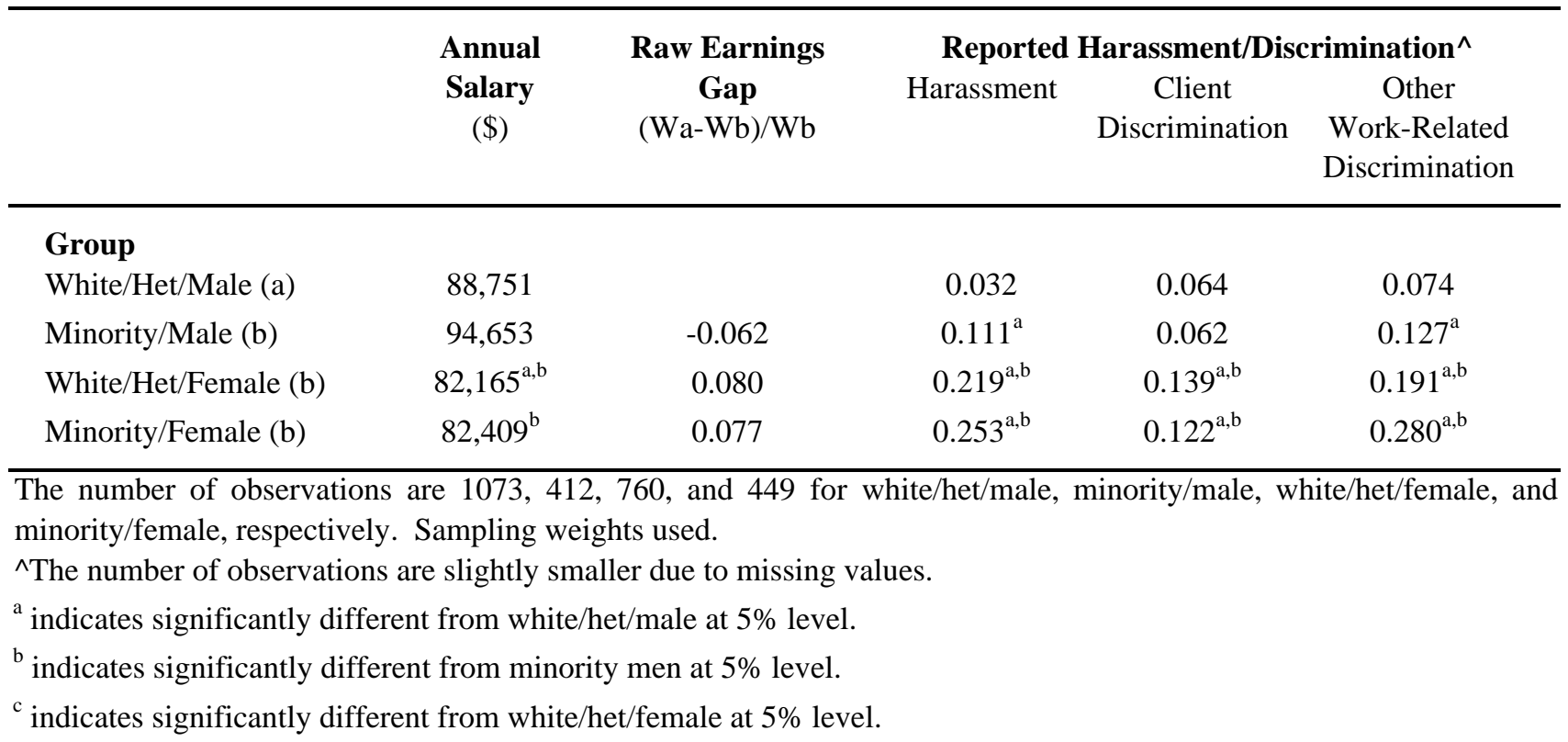


Table 2. Relationship between Reported Harassment and Reported Discrimination by Group (Conditional Means)

\begin{tabular}{|c|c|c|c|c|c|c|}
\hline & \multicolumn{2}{|c|}{ Harassment } & \multicolumn{2}{|c|}{ Client Discrimination } & \multicolumn{2}{|c|}{$\begin{array}{l}\text { Other Work-Related } \\
\text { Discrimination }\end{array}$} \\
\hline & $\begin{array}{c}0 \\
(1)\end{array}$ & $\begin{array}{c}1 \\
(2)\end{array}$ & $\begin{array}{c}0 \\
(3)\end{array}$ & $\begin{array}{c}1 \\
(4)\end{array}$ & $\begin{array}{c}0 \\
(5)\end{array}$ & $\begin{array}{c}1 \\
(6)\end{array}$ \\
\hline \multicolumn{7}{|l|}{ White/Het/Male } \\
\hline Harassment & & & $\begin{array}{c}0.026 \\
(\mathrm{n}=1000)\end{array}$ & $\begin{array}{l}\mathbf{0 . 0 9 6} \\
(\mathrm{n}=68)\end{array}$ & $\begin{array}{c}0.018 \\
(\mathrm{n}=1002)\end{array}$ & $\begin{array}{c}\mathbf{0 . 2 1 1} \\
(\mathrm{n}=68)\end{array}$ \\
\hline Client Discrimination & $\begin{array}{c}0.060 \\
(n=1033)\end{array}$ & $\begin{array}{c}\mathbf{0 . 2 0 6} \\
(\mathrm{n}=35)\end{array}$ & & & $\begin{array}{c}0.049 \\
(\mathrm{n}=1002)\end{array}$ & $\begin{array}{c}\mathbf{0 . 2 5 8} \\
(\mathrm{n}=67)\end{array}$ \\
\hline $\begin{array}{l}\text { Other Work-Related } \\
\text { Discrimination } \\
\text { Minority/Male }\end{array}$ & $\begin{array}{c}0.061 \\
(n=1034)\end{array}$ & $\begin{array}{l}0.487 \\
(n=36)\end{array}$ & $\begin{array}{c}0.057 \\
(\mathrm{n}=1001)\end{array}$ & $\begin{array}{l}\mathbf{0 . 2 9 1} \\
(\mathrm{n}=68)\end{array}$ & & \\
\hline Harassment & & & $\begin{array}{c}0.109 \\
(n=379)\end{array}$ & $\begin{array}{c}0.107 \\
(n=29)\end{array}$ & $\begin{array}{c}0.067 \\
(n=349)\end{array}$ & $\begin{array}{c}\mathbf{0 . 4 1 1} \\
(\mathrm{n}=60)\end{array}$ \\
\hline Client Discrimination & $\begin{array}{c}0.062 \\
(n=359)\end{array}$ & $\begin{array}{c}0.061 \\
(n=49)\end{array}$ & & & $\begin{array}{c}0.051 \\
(\mathrm{n}=349)\end{array}$ & $\begin{array}{l}0.142 \\
(\mathrm{n}=59)\end{array}$ \\
\hline $\begin{array}{l}\text { Other Work-Related } \\
\text { Discrimination }\end{array}$ & $\begin{array}{c}0.083 \\
(\mathrm{n}=359)\end{array}$ & $\begin{array}{l}\mathbf{0 . 4 7 0} \\
(\mathrm{n}=50)\end{array}$ & $\begin{array}{c}0.114 \\
(\mathrm{n}=379)\end{array}$ & $\begin{array}{c}0.284 \\
(n=29)\end{array}$ & & \\
\hline \multicolumn{7}{|l|}{ White/Het/Female } \\
\hline Harassment & & & $\begin{array}{c}0.189 \\
(n=653)\end{array}$ & $\begin{array}{c}\mathbf{0 . 3 9 4} \\
(\mathrm{n}=96)\end{array}$ & $\begin{array}{c}0.136 \\
(\mathrm{n}=611)\end{array}$ & $\begin{array}{c}\mathbf{0 . 5 6 9} \\
(\mathrm{n}=140)\end{array}$ \\
\hline Client Discrimination & $\begin{array}{c}0.106 \\
(n=588)\end{array}$ & $\begin{array}{c}\mathbf{0 . 2 4 9} \\
(\mathrm{n}=161)\end{array}$ & & & $\begin{array}{c}0.098 \\
(\mathrm{n}=611)\end{array}$ & $\begin{array}{c}\mathbf{0 . 3 0 0} \\
(\mathrm{n}=140)\end{array}$ \\
\hline $\begin{array}{l}\text { Other Work-Related } \\
\text { Discrimination }\end{array}$ & $\begin{array}{c}0.106 \\
(n=589)\end{array}$ & $\begin{array}{c}\mathbf{0 . 4 9 6} \\
(\mathrm{n}=162)\end{array}$ & $\begin{array}{c}0.155 \\
(n=655)\end{array}$ & $\begin{array}{l}\mathbf{0 . 4 2 0} \\
(\mathrm{n}=96)\end{array}$ & & \\
\hline Minority/Female & & & & & & \\
\hline Harassment & & & $\begin{array}{c}0.239 \\
(n=391)\end{array}$ & $\begin{array}{c}0.351 \\
(n=51)\end{array}$ & $\begin{array}{c}0.101 \\
(n=314)\end{array}$ & $\begin{array}{c}\mathbf{0 . 6 1 4} \\
(\mathrm{n}=130)\end{array}$ \\
\hline Client Discrimination & $\begin{array}{c}0.106 \\
(n=323)\end{array}$ & $\begin{array}{c}0.170 \\
(n=119)\end{array}$ & & & $\begin{array}{c}0.102 \\
(n=311)\end{array}$ & $\begin{array}{c}0.177 \\
(\mathrm{n}=130)\end{array}$ \\
\hline $\begin{array}{l}\text { Other Work-Related } \\
\text { Discrimination }\end{array}$ & $\begin{array}{c}0.143 \\
(n=326)\end{array}$ & $\begin{array}{c}\mathbf{0 . 7 0 2} \\
(\mathrm{n}=118)\end{array}$ & $\begin{array}{c}0.264 \\
(n=390)\end{array}$ & $\begin{array}{c}0.404 \\
(n=51)\end{array}$ & & \\
\hline
\end{tabular}

Bold (shaded) indicates the incidence of reported harassment/discrimination among those who do and do not report experiencing harassment/discrimination (i.e., column 1 vs. column 2, column 3 vs. column 4, and column 5 vs. column 6) are significantly different at the 5 (10) percent level. 
Table 3. Summary Statistics by Group

\begin{tabular}{|c|c|c|c|c|c|}
\hline \multirow{2}{*}{ Annual Hours } & \multirow[t]{2}{*}{ Total } & WHM & MMIN & WHF & MIN \\
\hline & & & & & \\
\hline Annual Hours & 2363.916 & 2393.655 & 2416.686 & 2322.996 & 2314.684 \\
\hline \multicolumn{6}{|l|}{ Demographic Characteristics } \\
\hline Age & 30.719 & 30.829 & 31.386 & 30.468 & 30.391 \\
\hline Married & 0.573 & 0.646 & 0.505 & 0.544 & 0.421 \\
\hline Presence of Children & 0.246 & 0.319 & 0.254 & 0.171 & 0.161 \\
\hline \multicolumn{6}{|l|}{ Educational Background } \\
\hline Law School Directly & 0.416 & 0.409 & 0.383 & 0.444 & 0.391 \\
\hline Pass Bar 1st Try & 0.887 & 0.910 & 0.821 & 0.898 & 0.824 \\
\hline \multicolumn{6}{|l|}{ Law School Ranking } \\
\hline Top 10 & 0.093 & 0.091 & 0.114 & 0.077 & 0.128 \\
\hline Top 11-20 & 0.097 & 0.087 & 0.112 & 0.097 & 0.127 \\
\hline Top 21-100 & 0.496 & 0.482 & 0.521 & 0.516 & 0.472 \\
\hline Tier 3 \& Lower & 0.314 & 0.340 & 0.253 & 0.310 & 0.273 \\
\hline \# of Additonal Job Offers & 2.894 & 3.085 & 2.970 & 2.648 & 2.778 \\
\hline \multicolumn{6}{|l|}{ Participation in: } \\
\hline Law Review & 0.431 & 0.418 & 0.403 & 0.457 & 0.429 \\
\hline Moot Court & 0.376 & 0.393 & 0.387 & 0.354 & 0.363 \\
\hline Pro Bono Work & 0.325 & 0.276 & 0.353 & 0.350 & 0.424 \\
\hline Leadership in Extra Curricular Activity & 0.396 & 0.326 & 0.478 & 0.425 & 0.521 \\
\hline Tenure & 1.341 & 1.324 & 1.279 & 1.358 & 1.421 \\
\hline \multicolumn{6}{|l|}{ Firm Characteristics } \\
\hline \multicolumn{6}{|l|}{ Type of Organization } \\
\hline Private Law Firm & 0.762 & 0.801 & 0.718 & 0.756 & 0.658 \\
\hline Solo Practice & 0.033 & 0.043 & 0.049 & 0.010 & 0.051 \\
\hline Government & 0.168 & 0.126 & 0.186 & 0.194 & 0.246 \\
\hline Other Organization & 0.037 & 0.030 & 0.048 & 0.040 & 0.045 \\
\hline Number of Lawyers at your location/firm & 78.916 & 73.527 & 90.823 & 79.896 & 87.178 \\
\hline \multicolumn{6}{|l|}{ Regional Wages } \\
\hline Regional Wages & 82366.710 & 79810.540 & 86792.940 & 82124.270 & 89586.450 \\
\hline Number of Observations & 2694 & 1073 & 412 & 760 & 449 \\
\hline
\end{tabular}

Sampling weights used. 
Table 4. Overall Wage Regressions Pooled by Group (OLS Coefficients and Standard Errors)

\begin{tabular}{lcccccc}
\hline & $(1)$ & $(2)$ & $(3)$ & $(4)$ & $(5)$ & $(6)$ \\
\hline Group & & & & & & \\
Minority/Male & 5901.41 & 5169.78 & 4648.76 & 3499.94 & 2868.89 & -177.73 \\
& $(3636.10)$ & $(3524.07)$ & $(3728.09)$ & $(3333.14)$ & $(3032.61)$ & $(3007.85)$ \\
White/Het/Female & $-6586.41^{\mathrm{a}, \mathrm{b}}$ & $-4230.51^{\mathrm{b}}$ & $-4282.67^{\mathrm{b}}$ & -3192.85 & -4232.44 & $-4915.76^{\mathrm{a}}$ \\
& $(3289.39)$ & $(3058.51)$ & $(2928.94)$ & $(2704.89)$ & $(2466.09)$ & $(2403.19)$ \\
Minority/Female & $-6342.50^{\mathrm{b}}$ & $-3749.98^{\mathrm{b}}$ & $-4012.08^{\mathrm{b}}$ & $-5517.28^{\mathrm{b}}$ & $-4530.28^{\mathrm{b}}$ & $-9295.77^{\mathrm{a}, \mathrm{b}}$ \\
& $(3389.47)$ & $(3185.02)$ & $(3437.81)$ & $(3036.47)$ & $(2768.08)$ & $(2976.90)$ \\
Characteristics & & & & & & \\
Annual Hours & No & Yes & Yes & Yes & Yes & Yes \\
Personal & No & No & Yes & Yes & Yes & Yes \\
Educational Background & No & No & No & Yes & Yes & Yes \\
Firm & No & No & No & No & Yes & Yes \\
Regional Wages & No & No & No & No & No & Yes \\
\hline
\end{tabular}

The number of observations are 2694. Sampling weights used.

${ }^{\mathrm{a}}$ indicates significantly different from white/het/male at $5 \%$ level.

${ }^{\mathrm{b}}$ indicates significantly different from minority men at $5 \%$ level.

${ }^{\mathrm{c}}$ indicates significantly different from white/het/female at $5 \%$ level. 
Table 5. Description of Measured Discrimination by Group

\begin{tabular}{|c|c|c|c|c|}
\hline & \multicolumn{4}{|c|}{ Group } \\
\hline & White/Het/Male & Minority/Male & White/Het/Female & Minority/Female \\
\hline & \multicolumn{4}{|c|}{ D1 } \\
\hline Mean & 0.00 & -422.91 & 5066.88 & 9372.93 \\
\hline \multicolumn{5}{|l|}{ Percentile } \\
\hline $25 \%$ & -14031.44 & -18614.42 & -9985.91 & -7329.34 \\
\hline $50 \%$ & 2654.05 & 4197.38 & 7464.67 & 9613.01 \\
\hline $75 \%$ & 19500.23 & 19914.29 & 23548.87 & 30540.90 \\
\hline \multirow[t]{2}{*}{$99 \%$} & 70519.64 & 67212.27 & 80661.42 & 73322.88 \\
\hline & \multicolumn{4}{|c|}{ D2 } \\
\hline Mean & 0.00 & -422.91 & 5066.88 & 9372.93 \\
\hline \multicolumn{5}{|l|}{ Percentile } \\
\hline $25 \%$ & 0.00 & -7075.41 & -5133.36 & 830.45 \\
\hline $50 \%$ & 0.00 & -386.50 & 5912.33 & 9018.69 \\
\hline $75 \%$ & 0.00 & 6692.11 & 13938.45 & 18205.00 \\
\hline $99 \%$ & 0.00 & 41320.31 & 42552.38 & 51044.52 \\
\hline Number of Observations & 1073 & 412 & 760 & 449 \\
\hline
\end{tabular}

D1equals predicted wages for white/het/male minus actual earnings for each individual. D2 equals predicted wages for white/het/male minus predicted wages based on group affilation for each individual. Underlying regressions for D1 and D2 include annual hours, demographic characteristics, educational background characteristics, firm characteristics, and regional wages. Sampling weights used. 
Table 6. The Effect of Measured Discrimination on Reported Harassment/Discrimination Pooled by Group (Probit Marginal Effects and Standard Errors)

\begin{tabular}{|c|c|c|c|c|c|c|c|c|c|}
\hline & \multicolumn{3}{|c|}{ Harassment } & \multicolumn{3}{|c|}{ Client Discrimination } & \multicolumn{3}{|c|}{ Other Work-Related Discrimination } \\
\hline & Model 1 & Model 2 & Model 3 & Model 1 & Model 2 & Model 3 & Model 1 & Model 2 & Model 3 \\
\hline \multicolumn{10}{|l|}{ Group } \\
\hline Minority/Male & $\begin{array}{c}\mathbf{0 . 1 3 5} \\
(0.033)\end{array}$ & $\begin{array}{c}\mathbf{0 . 1 3 1} \\
(0.033)\end{array}$ & $\begin{array}{c}\mathbf{0 . 1 3 2} \\
(0.034)\end{array}$ & $\begin{array}{c}0.004 \\
(0.019)\end{array}$ & $\begin{array}{c}0.002 \\
(0.019)\end{array}$ & $\begin{array}{c}0.001 \\
(0.019)\end{array}$ & $\begin{array}{c}\mathbf{0 . 0 5 3} \\
(0.028)\end{array}$ & $\begin{array}{c}\mathbf{0 . 0 5 2} \\
(0.028)\end{array}$ & $\begin{array}{c}\mathbf{0 . 0 5 4} \\
(0.028)\end{array}$ \\
\hline White/Het/Female & $\begin{array}{c}\mathbf{0 . 2 3 0} \\
(0.025)\end{array}$ & $\begin{array}{c}\mathbf{0 . 2 3 0} \\
(0.026)\end{array}$ & $\begin{array}{c}0.233 \\
(0.025)\end{array}$ & $\begin{array}{c}\mathbf{0 . 0 6 2} \\
(0.017)\end{array}$ & $\begin{array}{c}\mathbf{0 . 0 7 1} \\
(0.018)\end{array}$ & $\begin{array}{c}\mathbf{0 . 0 7 2} \\
(0.017)\end{array}$ & $\begin{array}{c}\mathbf{0 . 1 3 2} \\
(0.023)\end{array}$ & $\begin{array}{c}\mathbf{0 . 1 2 9} \\
(0.024)\end{array}$ & $\begin{array}{c}\mathbf{0 . 1 3 6} \\
(0.023)\end{array}$ \\
\hline Minority/Female & $\begin{array}{c}\mathbf{0 . 3 2 3} \\
(0.040)\end{array}$ & $\begin{array}{c}\mathbf{0 . 2 9 4} \\
(0.044)\end{array}$ & $\begin{array}{c}\mathbf{0 . 3 1 5} \\
(0.040)\end{array}$ & $\begin{array}{c}\mathbf{0 . 0 5 6} \\
(0.027)\end{array}$ & $\begin{array}{c}\mathbf{0 . 0 7 1} \\
(0.031)\end{array}$ & $\begin{array}{c}\mathbf{0 . 0 7 0} \\
(0.028)\end{array}$ & $\begin{array}{c}\mathbf{0 . 2 4 6} \\
(0.037)\end{array}$ & $\begin{array}{c}\mathbf{0 . 2 3 1} \\
(0.041)\end{array}$ & $\begin{array}{c}\mathbf{0 . 2 4 1} \\
(0.037)\end{array}$ \\
\hline \multicolumn{10}{|l|}{ Measured Discrimination } \\
\hline $\mathrm{D} 1 / 10000$ & $\begin{array}{c}0.006 \\
(0.004)\end{array}$ & & & $\begin{array}{c}\mathbf{0 . 0 0 7} \\
(0.003)\end{array}$ & & & $\begin{array}{c}0.001 \\
(0.002)\end{array}$ & & \\
\hline $\mathrm{D} 2 / 10000$ & & $\begin{array}{c}0.003 \\
(0.007)\end{array}$ & & & $\begin{array}{c}0.002 \\
(0.006)\end{array}$ & & & $\begin{array}{c}0.012 \\
(0.008)\end{array}$ & \\
\hline \multirow[t]{2}{*}{$\begin{array}{l}\text { Measured Discrimination*Group } \\
\text { (D1/10000)*Minority Male }\end{array}$} & -0.008 & & & -0.006 & & & 0.002 & & \\
\hline & $(0.005)$ & & & $(0.006)$ & & & $(0.005)$ & & \\
\hline (D1/10000)*White/Het/Female & $\begin{array}{c}-0.002 \\
(0.004)\end{array}$ & & & $\begin{array}{c}0.004 \\
(0.005)\end{array}$ & & & $\begin{array}{c}0.004 \\
(0.004)\end{array}$ & & \\
\hline (D1/10000)*Minority/Female & $\begin{array}{c}-0.008 \\
(0.005)\end{array}$ & & & $\begin{array}{c}0.003 \\
(0.007)\end{array}$ & & & $\begin{array}{l}-0.005 \\
(0.004)\end{array}$ & & \\
\hline (D2/10000)*Minority Male & & $\begin{array}{l}-0.008 \\
(0.013)\end{array}$ & & & $\begin{array}{c}0.007 \\
(0.011)\end{array}$ & & & $\begin{array}{c}0.009 \\
(0.014)\end{array}$ & \\
\hline (D2/10000)*Minority/Female & & $\begin{array}{c}0.007 \\
(0.011)\end{array}$ & & & $\begin{array}{l}-0.005 \\
(0.013)\end{array}$ & & & $\begin{array}{l}-0.007 \\
(0.013)\end{array}$ & \\
\hline \multicolumn{10}{|l|}{ Characteristics } \\
\hline Annual Hours & Yes & Yes & Yes & Yes & Yes & Yes & Yes & Yes & Yes \\
\hline Demographic & Yes & Yes & Yes & Yes & Yes & Yes & Yes & Yes & Yes \\
\hline Educational Background & Yes & Yes & Yes & Yes & Yes & Yes & Yes & Yes & Yes \\
\hline Firm & Yes & Yes & Yes & Yes & Yes & Yes & Yes & Yes & Yes \\
\hline Regional Wages & Yes & Yes & Yes & Yes & Yes & Yes & Yes & Yes & Yes \\
\hline
\end{tabular}

The number of observations are 2678, 2673, and 2678 for harassment, client discrimination, and other work-related discrimination, respectively. D1 equals predicted wages for white/het/male minus actual earnings for each individual. D2 equals predicted wages for white/het/male minus predicted wages based on group affilation for each individual. The underlying regressions for D1 and D2 include annual hours, demographic characteristics, educational background, firm characteristics, and regional wages. Sampling weights used. Bold (shaded) indicates signficant at the 5 (10) \% level. 
Appendix Table 1. Variable Definitions

\begin{tabular}{l}
\hline Variable Name \\
\hline Demographic Character $^{\text {a }}$ \\
Age $^{\mathrm{a}}$ \\
Marital Status \\
Presence of Children \\
Educational Background \\
Law School Directly \\
\\
Pass Bar 1st Try \\
Law School Ranking \\
Top 10 \\
Top 11-20 \\
Top 21-100 \\
Tier 3 \& Lower \\
\# of Additonal Job Offers \\
Participation in: \\
Law Review \\
Moot Court \\
Pro Bono Work \\
Leadership in Extra \\
Curricular Activity \\
Tenure \\
\end{tabular}

\section{Firm Characteristics} Type of Organization Private Law Firm Solo Practice

Government Variable Definition

\section{Demographic Characteristics}

equal to the survey year (2002) minus the respondent's year of birth. equal to one if the respondent reported that they were married for the first time or were remarried after previously being divorced/widowed/annulment, and zero otherwise equal to one if the number of kids who live with the respondent for a significant part of the year is one or more, and zero otherwise.

equal to one if the respondent went to law school directly from their undergraduate degree, and zero otherwise

equal to one if the respondent passed their bar exam for the state in which they are currently working on the first try, and zero otherwise (including missing values).

equal to one if the respondent's law school ranked in the Top 10, and zero otherwise. equal to one if the respondent's law school ranked in the Top 11-20, and zero otherwise. equal to one if the respondent's law school ranked in the Top 21-100, and zero otherwise. equal to one if the respondent's law school ranked in Tier 3 \& lower, and zero otherwise. equal to the number of additional job offers (public \& private) the respondent had.

equal one for those respondents who report participating in law review and zero otherwise equal one for those respondents who report participating in moot court and zero otherwise equal one for those respondents who report participating in pro bono work and zero otherwise equal to one if the new lawyer played a leadership role in any extra-curricular activity, and zero otherwise (including missing values).

equal to the survey date (month/year) minus the current job date (month/year) divided by 12 to convert the value into years. Negative values were set equal to zero.

Other Organization

equal to one if the respondent works in a private law firm, and zero otherwise. equal to one if the respondent works in a private law firm, and zero otherwise. equal to one if the respondent works in a government organizations (i.e., Federal, State/Local, legal services or public defender, public interest), and zero otherwise.

equal to one if the respondent works in other organization (i.e., professional service firm, other fortune 1000 industry/service, other business/industry, educational, labor union trade association, other). , and zero otherwise.

Number of Lawyers at your equal to the number of lawyers at your location, however if this information is missing we location/firm used the number of lawyers at the entire firm.

Regional Wages

Regional Wages ${ }^{\mathrm{e}}$

equal to the average annual earnings of all AJD respondents in a given region (New York City, District of Columbia, Chicago, Los Angeles, Atlanta, Houston, Minneapolis, San Francisco, Connecticut, New Jersey, Florida, Tennessee, Oklahoma, Indiana, St. Louis, Utah, Oregon, and Boston) before any eligible observations were dropped from the analysis.

Notes:

a. For those respondents that had missing year of birth, we calculated age as the survey year (2002) minus the year of their undergraduate degree minus 16 (the average number of years to acquire an undergraduate degree) minus 5 (the average number of years prior to entering kindergarten).

b. For those respondent's for whom this information was missing (3 observations), we assume they did not go to law school directly. We confirmed this was a reasonable assumption by looking at the year of graduation for the undergraduate degree and the year of graduation for the law school degree.

c. The law school ranking is based on the U.S. News (2003) ranking of the respondent's law school.

d. The survey year was 2002; the survey months included July, March, and September. The majority of the respondents were surveyed in March. One respondent had missing information on the month of the current job, for this individual we simply subtracted the year of the current job from the survey year (2002). Finally, for those respondents (12 observations) with missing information on the current job date (both month and year) we used the year they passed the bar exam (in the first state mentioned) and subtracted that year from the survey year (2002).

e. The AJD included 815 respondents who were not eligible in Wave 1, leaving a total sample size of 4,538 observations. 